\title{
A high pressure low temperature study on rare earth compounds semiconductor to metal transition
}

\section{Doctoral Thesis}

Author(s):

Neuenschwander, Jürg

Publication date:

1988

Permanent link:

https://doi.org/10.3929/ethz-a-000517979

Rights / license:

In Copyright - Non-Commercial Use Permitted 
Diss. ETH No. 8668

\title{
A High Pressure Low Temperature Study on Rare Earth Compounds: Semiconductor to Metal Transition
}

\author{
A dissertation \\ submitted to the \\ SWISS FEDERAL INSTITUTE OF TECHNOLOGY \\ ZÜRICH \\ for the degree of \\ Doctor of Natural Sciences \\ presented by \\ JÜRG NEUENSCHWANDER \\ Dipl. Phys. ETHZ \\ born April 24, 1958, \\ citizen of Langnau i.E., BE.
}

Accepted on the recommendation of

Prof. Dr. P. Wachter, examiner, Prof. Dr. W. Baltensperger, co-examiner. 


\section{Abstract}

Many rare earth monochalcogenides exhibit under pressure a semiconductor to metal transition (SMT) and concomitant a change in valence of their rare earth ions. In this work we present and discuss high pressure low temperature experiments on single crystalline semiconducting $\mathrm{TmSe}_{1-x} \mathrm{Te}_{x}(x=0.55,0.68), \mathrm{Tm}_{1-x} \mathrm{Eu}_{x} \mathrm{Se}$ $(x=0.5)$, and $\mathrm{SmS}_{1-x} \mathrm{Se}_{x}(x=0.11,0.44)$ alloys. At room temperature all of them reveal a steady decrease of the electrical resistivity $\rho$ with increasing pressure $p$ indicating the closing of the energy gap. As the metallic state is achieved the resistivity becomes essentially pressure independent. In $\mathrm{TmSe}_{0.45} \mathrm{Te}_{0.55}$ and $\mathrm{TmSe}_{0.32} \mathrm{Te}_{0.68}$ at temperatures below $\sim 250 \mathrm{~K}$ and most prominent at $5 \mathrm{~K}$, however, we observe in the semiconducting regime an unusual peak structure in the resistivity-pressure relation. With neutron diffraction no crystallographic phase transition is discernible; and magnetic susceptibility and magnetoresistance data make it unlikely that the phenomenon is due to magnetic interactions. We propose the electron-hole interaction to play an important role in $\mathrm{TmSe}_{1-x} \mathrm{Te}_{x}$ under pressure and speculate that the resistance anomaly is triggered by an excitonic instability. We can derive for these compounds a temperature-energy-gap phase diagram which is typical for an excitonic insulator. Optical reflectivity measurements on $\mathrm{TmSe}_{0.45} \mathrm{Te}_{0.55}$ at ambient pressure give evidence that the necessary presupposition for the occurence of an excitonic insulator-the presence of an excitonic level within the energy gap-is fulfilled. The significant temperature dependence of the $\rho(p)$ peak height is successfully described with a simple model which is based on the admixture of $f$ character into the $d$ conduction band with a corresponding decrease of mobility of carriers. No similar effect in $\rho(p)$ at low temperatures has been observed in $\mathrm{Tm}_{0.5} \mathrm{Eu}_{0.5} \mathrm{Se}$ or $\mathrm{SmS}_{0.89} \mathrm{Se}_{0.11}$. Nevertheless, we have reasons to expect Se rich $\mathrm{SmS}_{1-x} \mathrm{Se}_{x}$ compounds to be good candidates to exhibit also this peak structure at low temperatures. The character of the pressure induced SMT in $\mathrm{TmSe}_{0.45} \mathrm{Te}_{0.55}$ changes from continuous at room temperature to discontinuous at temperatures below $\sim 200 \mathrm{~K}$. In the same compound a pressure induced transition from weak antiferromagnetism $\left(T_{N}<0.4 \mathrm{~K}\right.$; semiconducting state) to ferromagnetism (maximum $T_{C} \approx 6 \mathrm{~K}$; metallic state) is observed.

$\operatorname{Tm}_{0.5} \mathrm{Eu}_{0.5} \mathrm{Se}$ is a ferromagnetic semiconductor $\left(T_{C}=16 \mathrm{~K}\right)$. The electrical resistivity in the range $100-300 \mathrm{~K}$ is predominantly of extrinsic character, but near the ordering point a pronounced peak in $\rho(T)$ occurs, and in the ordered region the resistivity becomes significantly reduced. This behavior is thought to be due to the spin disorder scattering and the exchange induced splitting of the conduction band (magnetic red shift). For pressures up to 9 kbar magnetic susceptibility measure- 


\section{Abstract}

ments indicate a considerable increase of the ordering temperature with a rate of nearly $1 \mathrm{~K} / \mathrm{kbar}$. The resistivity peak shifts under pressure with the same rate to higher temperatures, but its height becomes reduced, presumeably due to the presence of more free electrons (liberated $4 f$ electrons). The susceptibility measurements suggest a pressure induced ferromagnetism to antiferromagnetism (with $T_{N} \approx 10 \mathrm{~K}$ ) transition concomitant to the pressure induced SMT. The situation is considerably complicated by the magnetic red shift of the energy gap.

In $\mathrm{SmS}_{0.56} \mathrm{Se}_{0.44}$ we have measured the volume-pressure relation at room temperature. We find this material to become very soft before the first-order valence transition occurs (at $23.7 \mathrm{kbar}$ ). This is in contrast to $\mathrm{SmS}$ which remains stiff up to the valence transition. Hence $\mathrm{SmS}_{0.56} \mathrm{Se}_{0.44}$ is similar to the $\mathrm{TmSe}_{1-x} \mathrm{Te}_{x}$ compounds which, even if the transition is first-order $(x=0.4)$, exhibit a signifcant softening of the lattice. We are left with the speculation that in analogy to $\mathrm{TmSe}_{0.32} \mathrm{Te}_{0.68}$ also in $\mathrm{SmS}_{0.56} \mathrm{Se}_{\mathbf{0 . 4 4}}$ Poisson's ratio might become negative already in the semiconducting state. 


\section{Zusammenfassung}

Viele Monochalkogenide der Seltenen Erden zeigen einen druckinduzierten Halbleiter-Metall Übergang, damit verbunden ist eine Änderung der Valenz der Ionen der Seltenen Erden. In dieser Arbeit präsentieren und diskutieren wir HochdruckTieftemperatur Experimente an einkristallinen, halbleitenden $\operatorname{TmSe}_{1-x} \mathrm{Te}_{x}(x=$ $0.55,0.68), \mathrm{Tm}_{1-x} \mathrm{Eu}_{x} \mathrm{Se}(x=0.5)$, und $\mathrm{SmS}_{1-x} \mathrm{Se}_{x}(x=0.11,0.44)$ Verbindungen. Bei Zimmertemperatur zeigen alle diese Proben eine monotone Abnahme des elektrischen Widerstandes $\rho$ mit zunehmendem Druck $p$, was auf das Schliessen der Energielücke zurückzuführen ist. Sobald der metallische Zustand erreicht ist, wird der Widerstand praktisch druckunabhängig. In $\mathrm{TmSe}_{0.45} \mathrm{Te}_{0.55}$ und $\mathrm{TmSe}_{0.32} \mathrm{Te}_{0.68}$ beobachten wir jedoch bei Temperaturen unterhalb $\sim 250 \mathrm{~K}$, und am ausgeprägtesten bei $5 \mathrm{~K}$, im halbleitenden Bereich ein höchst seltsames Maximum in den Widerstands-Druck Kurven. Neutronenstreuung zeigt keine kristallographische Phasenumwandlung an. Im weiteren schliessen wir aus Messungen der magnetischen Suszeptibilität und des Magnetowiderstandes, dass es unwahrscheinlich ist, dass das Phänomen auf magnetische Wechselwirkungen zurückzuführen ist. Wir sind der Ansicht, dass die Elektron-Loch Wechselwirkung in $\mathrm{TmSe}_{1-x} \mathrm{Te}_{x}$ unter Druck eine bedeutende Rolle spielt und spekulieren, dass die Anomalie im Widerstand durch eine exzitonische Instabilität ausgelöst wird. Wir erhalten für diese Verbindungen ein Temperatur-Energielücke Phasendiagramm, welches typisch ist für einen exzitonischen Isolator. Optische Reflektivitätsmessungen an $\mathrm{TmSe}_{0.45} \mathrm{Te}_{0.55}$ bei Normaldruck geben Evidenz, dass die notwendige Voraussetzung für das Auftreten eines exzitonischen Isolators-die Existenz eines exzitonischen Niveaus innerhalb der Energielücke-erfüllt ist. Die bedeutende Temperaturabhängigkeit des Maximums von $\rho(p)$ kann erfolgreich mit einem einfachen Modell beschrieben werden. Dieses basiert auf der Beimischung von $f$-Charakter zum $d$-Leitungsband mit entsprechender Abnahme der Beweglichkeit der Ladungsträger. Kein vergleichbarer Effekt in $\rho(p)$ bei tiefen Temperaturen wurde in $\mathrm{Tm}_{0.5} \mathrm{Eu}_{0.5} \mathrm{Se}$ oder $\mathrm{SmS}_{0.89} \mathrm{Se}_{0.11}$ beobachtet. Allerdings gibt es Gründe anzunehmen, dass Se-reiche $\mathrm{SmS}_{1-x} \mathrm{Se}_{x}$ Verbindungen gute Kandidaten sind, um bei tiefen Temperaturen ein vergleichbares Maximum in den Widerstands-Druck Kurven zu zeigen. Der druckinduzierte Halbleiter-Metall Übergang in $\mathrm{TmSe}_{0.45} \mathrm{Te}_{0.55}$ vollzieht sich kontinuierlich bei Zimmertemperatur, unterhalb $\sim 200 \mathrm{~K}$ ist der Übergang dann aber sprunghafter Natur. In derselben Verbindung beobachtet man einen druckinduzierten Übergang von einem schwachen Antiferromagneten ( $T_{N}<0.4 \mathrm{~K}$; halbleitender Zustand) zu einem Ferromagneten (maximales $T_{C} \approx 6 \mathrm{~K}$; metallischer Zustand).

$\mathrm{Tm}_{0.5} \mathrm{Eu}_{0.5} \mathrm{Se}$ ist ein ferromagnetischer Halbleiter $\left(T_{C}=16 \mathrm{~K}\right)$. Der elektrische 


\section{Zusammenfassung}

Widerstand ist im Bereich 100-300 K hauptsächlich extrinsischen Charakters, nahe des Ordnungspunktes tritt dann aber eine ausgeprägte Spitze in $\rho(T)$ auf, und im magnetisch geordneten Zustand ist der Widerstand markant reduziert. Dieses Verhalten wird auf Spin-Disorder-Streuung und austauschinduzierte Aufspaltung des Leitungsbandes (Rotverschiebung) zurückgeführt. Für Drücke bis gegen $9 \mathrm{kbar}$ zeigen Messungen der magnetischen Suszeptibilität eine bedeutende Zumnahme der Ordnungstemperatur mit nahezu $1 \mathrm{~K} / \mathrm{kbar}$. Die Widerstandsspitze verschiebt sich dabei mit derselben Rate $z u$ höheren Temperaturen, wobei ihre Höhe allerdings reduziert wird, was wahrscheinlich auf das Vorhandensein von zusätzlichen freien Elektronen (delokalisierte $4 f$ Elektronen) zurückzuführen ist. Die Suszeptibilitätsmessungen deuten zudem daraufhin, dass der druckinduzierte Halbleiter-Metall Übergang begleitet wird von einem Ferromagnetismus-Antiferromagnetismus (mit $T_{N} \approx$ $10 \mathrm{~K})$ Übergang. Die Situation ist erheblich kompliziert durch die magnetische Rotverschiebung der Energielücke.

An $\mathrm{SmS}_{0.56} \mathrm{Se}_{0.44}$ haben wir bei Zimmertemperatur die Volumen-Druck-Kurve gemessen. Wir finden, dass dieses Material vor dem Valenzübergang 1.Ordnung (bei 23.7 kbar) sehr weich wird. Dieser Befund steht im Gegensatz zu SmS, welches bis hin zum Valenzübergang steif bleib. $\mathrm{SmS}_{0.56} \mathrm{Se}_{0.44}$ ist somit den $\mathrm{TmSe}_{1-x} \mathrm{Te}_{x}$ Verbindungen ähnlich, die sogar im Falle eines sprunghaften Übergangs $(x=0.4)$ eine ausserordentliche Abnahme des Kompressionsmoduls aufweisen. Wir spekulieren, dass, in Analogie zu TmSe $e_{0.32} \mathrm{Te}_{0.68}$ auch in $\mathrm{SmS}_{0.56} \mathrm{Se}_{0.44}$ die Poissonzahl bereits im halbleitenden Zustand negativ werden könnte. 